\title{
Effect of aeration on physicochemical, color and texture characteristics of confectionery foams
}

\author{
Raluca-Olimpia Zimbru, Sergiu Pădureţ, Sonia Amariei
}

\author{
Stefan cel Mare University of Suceava, Suceava, Romania
}

\section{Keywords:}

Confectionery

Foams

Air bubbles

Texture

Color

\section{Article history: \\ Received 15.06.2019 \\ Received in revised \\ form 20.10.2019 \\ Accepted 30.03.2020}

\section{Corresponding author:}

Sergiu Pădureț

E-mail:

sergiu.paduret@

fia.usv.ro

DOI: $10.24263 / 2304-$

974X-2020-9-1-9

\section{Abstract}

Introduction. The aim of this research was to determine the aeration process effect and the importance of raw materials on the quality characteristics of foams used in confectionery.

Materials and methods. The application of two different techniques and using raw materials of different origin (cream $-\mathrm{S} 2$, $\mathrm{S} 4$ and vegetable cream - S1, S3) were the basis for obtaining the foam samples, which have been analyzed in terms of chemical composition, porosity, color parameters and texture properties. The samples porosity was measured using ImageJ software (NIH Image) and the primary and secondary texture parameters were achieved by texture profile analysis test with Mark 10-ESM 301 Texture Analyzer.

Results and discussion. The highest fat content of confectionery foams was observed for cream-based samples $(20.35 \%)$, while the vegetable cream-based samples presented lower value $(15 \%)$. The moisture content of analyzed confectionery samples varied from 43.59 to $47.68 \%$, the difference of moisture content according to sample classification (S1-S4) being significant $(p<0.01)$. The highest concentrations of soluble substances, 26.25 and 26.40 , were presented by vegetable creambased samples; S1 and S3 foam samples belonging to the same statistical group. The water activity of foam samples ranged from 0.804 to 0.824 , the $\mathrm{S} 4$ cream-based samples presented the highest value. The samples porosity varied between 15.27 and $7.04 \%$. The diameter of the air bubbles ranged between $4.36 \mathrm{~mm}$ to a few micrometers, the samples porosity having a negative influence on both primary $\left(\mathrm{r}=-0.946^{*}\right)$ and secondary $\left(\mathrm{r}=-0.967^{*}\right)$ texture properties. The brightness of vegetable cream-based samples presented the highest values (92.77 and 93.64), which means that this samples are whiter and brighter than the cream-based foams (89.74 and 86.89); while, b* color parameter, which represents yellow-blue axis showed high values for cream-based samples (28.71 and 34.09). The texture profile analysis results showed that the highest hardness is shown by S3 sample $-3.48 \mathrm{~N}$, the other foam samples showing close values ranging between 1.52 and 1.76 $\mathrm{N}$. The samples with a low porosity had high hardness values, high levels of fracturability $(0.24 \mathrm{~N})$, which implies a more compact and brittle product, with a high viscosity (0.64), gumminess (1.53), chewiness (1.31) and cohesiveness (39.82).

Conclusions. Besides the influence on the firmness and other texture parameter, the aeration process changes the product appearance, color properties and mouth-feel. 


\section{Introduction}

Many food products, especially those of bakery, pastry and confectionery [1, 2], depend on the aeration process to develop a certain structure, which can be obtained by biological, mechanical or chemical methods. An alternative to these methods is represented by the continuous aeration, in which the air phase is dispersed by mechanical action (shear and elongation flow forces) into the continuous phase [3]. A great importance in the continuous aeration process of food matrix is that the air phase must be concomitantly dispersed and stabilized [4, 5]. Air bubbles are an integral part in many confectionery products such as: meringues, marshmallow, mousses, whipped cream, nougat or aerated chocolate [6]; the aeration process being used to generate a range of novel textural properties [7-9]. Along with increasing volume, lowering density, improving the palatability and sensory appeal, the aeration process determines an increase in the viscosity and a decrease in fluidity of the product during processing, reduces stickiness and, ultimately, modifies the appearance, structure, textural characteristics, lightens the color of the products and changes the sensory properties (a lighter mouth-feel) of the finished product [10]. The air phase used in aeration processes must comply with certain conditions, such as free from all contaminants, without particulates, without oil droplets, odorless, dry and without microorganisms $[10,8]$. The stability and comportment of confectionery foams are closely connected to their microstructure, and more precisely, to the air void dimension, distribution and volume fraction; the foams with smaller bubbles and with a uniform distribution of them exhibit the best textural parameters, flow behavior and stability over time, being creamier and more interesting to consumers [11]. Air bubbles are influenced by the process conditions, such as the residence time, the mixing head geometry and its operating conditions, the mechanism of the air bubbles can be applied also to assess the shelf life of whipped dairy products, since the textural properties and mouth-feel are a direct result of the elaborate interactions between bubble mechanics and human senses [4, 11]. Fixing air in the food structure is of great importance for producers which see air bubbles as a novel and versatile food ingredient used to produce a range of new textures from crunchy or crisp to soft one. To the authors knowledge there are few research about aerated confectionery. Therefore, the purpose of this research is to determine the effect of the aeration process and the importance of raw materials on the quality characteristics, color and texture of foams used in confectionery.

\section{Materials and methods}

\section{Materials and experimental products preparation}

The confectionery foams samples were produced in industrial conditions at SC. MOPAN S.A. company (Suceava, Romania). For samples preparation cream, vegetable cream, milk, white chocolate, sugar, gelatin and yolk were used (Figure 1 and 2). The gelatin was used as a stabilizing agent for the foam's air cells. The samples aeration was performed by mechanical whipping process using a planetary mixer (KitchenAid), the speed being set to 1000 rotations/min, using a six wire whip attachment and the whipping time was set to 5 minutes.

The foam samples were prepared as follows: for S1 and S2 samples (Figure 1) the sugar and yolk was whipped and mixed with hot milk, tempered chocolate and hydrated gelatin; this mixture was incorporated in the whipped cream and vegetable whipped cream. For S3 and S4 samples (Figure 2) in the whipped cream and vegetable whipped cream were 
incorporated other ingredients starting with the mixture between sugar syrup and whipped yolk and followed by tempered chocolate and hydrated gelatin.

The S1 and S3 samples are vegetable cream-based foams, while S2 and S4 are creambased foams. Prior to the analysis, the samples were kept under refrigeration conditions for 12 hours.

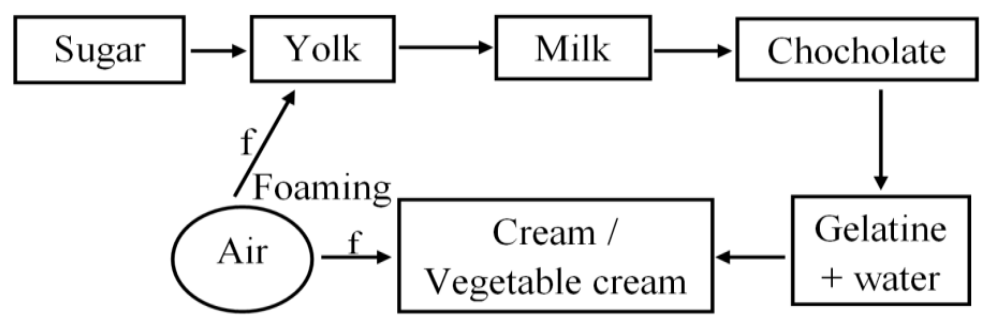

Figure 1. The structural design of S1 and S2 confectionery foams: s-solution; f-foaming.

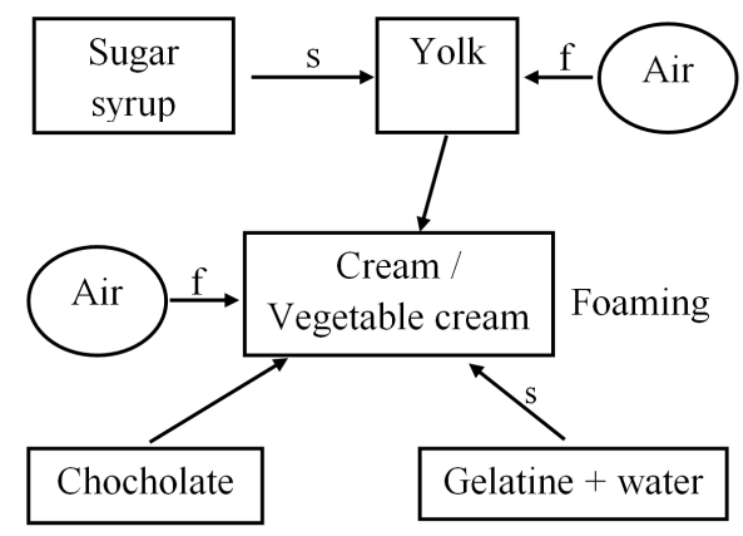

Figure 2. The structural design of $\mathrm{S3}$ and $\mathrm{S4}$ confectionery foams: $\mathrm{s}$ - solution; $\mathbf{f}$ - foaming.

\section{Physicochemical parameters}

The moisture content of foams samples were determined by oven drying method (103 \pm $2^{\circ} \mathrm{C}$ ), [12] and then expressed as percent, the protein content was determined by Kjeldhal method [13] and expressed as percent of wet basis. The Soxhlet method [14] was applied to determine the fat content and the results were expressed as percent of wet basis. Total acidity was measured by direct titration with $\mathrm{NaOH} 0.1 \mathrm{~N}$, expressed as $\mathrm{cm}^{3} \mathrm{NaOH} / 100 \mathrm{~g}$ sample and the $\mathrm{pH}$ was determined using a Metter Toledo $\mathrm{pH}$-meter [15]. The confectionery foams' soluble substances concentrations $\left({ }^{\circ}\right.$ Brix) were determined by a Leica Mark II Plus refractometer, with an accuracy of $0.1 \%$ and the water activity was measured with a water 
activity meter (AquaLab Lite). The foam porosity was measured using the ImageJ software (NIH Image) and expressed as percentage. The color measurements were achieved with a CR-400 Chroma meter from Konica Minolta (Konica Minolta, Japan) using the CIE L*a*b* uniform color space method, where: $\mathrm{L}^{*}$ represents brightness, $\mathrm{a}^{*}$ represents red-green axis and $\mathrm{b}^{*}$ represents yellow-blue axis. Hue angle or tone $\left(\mathrm{h}^{0}\right)$, chroma or color intensity $\left(\mathrm{C}^{*}\right)$ and yellowness index (YI) was calculated as follows (eq.1-3), [16, 17].

$$
\begin{gathered}
\mathrm{h}^{0}=\tan ^{-1}\left(\mathrm{~b}^{*} / \mathrm{a}^{*}\right) \\
\mathrm{C}^{*}=\left(\mathrm{a}^{* 2}+\mathrm{b}^{* 2}\right)^{1 / 2} \\
Y I=\frac{142.86 b^{*}}{L^{*}}
\end{gathered}
$$

\section{Texture profile analysis}

Texture measurements were carried out on confectionery foams samples at ambient temperature with Mark 10-ESM 301 Texture Analyzer (Mark 10 Corporation, USA) with a loading-unloading speed of $10 \mathrm{~mm} / \mathrm{min}$ using compression discs of $5 \mathrm{~cm}$ diameter, the foam samples being compressed to $50 \%$ of its original size [18]. The confectionery foams samples had cubic shape with side of $30 \mathrm{~mm}$ and subjected to a texture profile analysis - TPA test [19]. The experimental data obtained from TPA test were used to calculate primary textural parameters like: hardness $(\mathrm{H})$, viscosity $(\mathrm{V})$, adhesiveness $(\mathrm{A})$, cohesiveness (Co), springiness $(\mathrm{S})$, and secondary textural parameters gumminess $(\mathrm{G})$, chewiness $(\mathrm{Ch})$ and fracturability (F), [20].

All physicochemical measurements were carried out in triplicate. All the reagents were of analytical grade.

\section{Statistical analysis}

The analyzed foams results were subjected to analysis of variance ANOVA using STATGRAPHICS CENTURION XVI (Trial Version) and Pearson correlation with SPSS 13.0 (SPSS Inc. Chicago, IL).

\section{Results and discussion}

\section{Physicochemical analysis}

The physicochemical parameters (fat, protein, moisture content, Brix concentration, $\mathrm{a}_{\mathrm{w}}$, free acidity, $\mathrm{pH}$ ) and color parameters ( $\mathrm{L}^{*}, \mathrm{a}^{*}, \mathrm{~b}^{*}$, chroma, yellowness index, hue angle) of confectionery foam samples are shown in Table 1 . The confectionery foams' fat content varied between 15.00 and $20.35 \%$, the highest fat content was observed for cream-based foams (S2, S4); while the vegetable cream-based foams (S1, S3) presented lower value. The results of one factor analysis of variance (ANOVA) indicated that the difference is statically significant $(\mathrm{p}<0.05)$. The protein content of analyzed confectionery foams is in the same range $(9.70-10.20 \%)$, the statistical difference being insignificant $(\mathrm{p}>0.05)$.

Water is an important component of confectionery products, one of the main functions being to solubilize the raw materials and help mixing them. The water content influences the 
product texture properties and is one important factor affecting the shelf life [21]. Moisture content has a significant contribution on the texture of confectionery products; the moisture content of analyzed confectionery samples varied from 43.59 to $47.68 \%$, the difference of moisture content according to sample classification (S1-S4) was significant at a level of $\mathrm{p}<$ 0.01. According to Fontana, 2006 [22] the water activity of confectionery products has a significant role in quality assurance, processing, shelf life, sensory and texture properties evaluation. Confectionery products such as boiled sweets, toffees, caramels, jellies, creams or coatings cover a wide range of water activities $\left(\mathrm{a}_{\mathrm{w}}\right)$ from 0.2 to 0.9 [22]. The water activity of foam samples ranged from 0.804 to 0.824 , the $\mathrm{S} 4$ cream-based samples having the highest value. The concentration of soluble substances express as ${ }^{\circ}$ Brix ranged between 23.50 (S2) to 26.40 (S3), the highest Brix concentration was presented by vegetable cream-based samples (S1, S3 - samples belonging to the same statistical group), one-factor analysis of variance highlighted this difference at a level of $\mathrm{p}<0.01$. The measured $\mathrm{pH}$ values of confectionery foam samples were in the slightly acidic zone, showing values close to each other (6.67-6.78). The total acidity of the confectionery products is due to the organic acids used (the citric, malic, tartaric, lactic or acetic acid are commonly used), [23] or due to the raw materials used in the production process and it has the role to extend or enhance tartness or sour perception in addition to the product specific functions and also to control the textural characteristics of the product [24]. The total acidity of the analyzed foams belongs to the same statistical group, (ANOVA), $p>0.05$, the difference being insignificant. A relatively novel approach to create new products is fixing air into food structure, thus obtaining products with a low caloric intake, new texture characteristics, new appearance, color and a modification in the mouth feel [9]. The samples porosity varied between 15.27 and $7.04 \%$, also the difference being insignificant $(\mathrm{p}>0.05)$. However, introducing air or another gas into a food matrix makes the finished product lighter; increasing the final volume and the texture becomes softer.

In Table 1 there are presented also the color parameters of confectionery foam samples. Color is an important characteristic of food products, being the first quality attribute evaluated by the consumers and especially of confectionery products; consumers choosing products according to their color characteristics and appearance [25]. The confectionery products come in a wide range of colors from the ingredients used or from the addition of food coloring. In terms of brightness $-\mathrm{L}^{*}$, we can observe that $\mathrm{S} 1$ and $\mathrm{S} 3$ foam vegetable cream-based samples present the highest values, which means that this samples are whiter and brighter than the cream-based foams (S2 and S4), p < 0.001. Instead, b* color parameter, which represents yellow-blue axis showed high values for S2 (28.71) and S4 (34.09) foam samples. In case of $\mathrm{a}^{*}$ color parameter (red-green axis) all foam samples presented negative values ranging between -7.17 and -5.35 , more toward green. The lowest color intensity $\left(\mathrm{C}^{*}\right)$ values were observed for vegetable cream-based samples, while the cream-based sample (S4) had the highest values. The cream-based samples S2 and S4 presented also the highest yellowness index. One way ANOVA analysis highlighted that all color parameters were different accordingly to the ingredients used and the technology applied in the production process $(\mathrm{p}<0.001)$. 
Table 1

Physicochemical and color parameters of confectionery foams

\begin{tabular}{|c|c|c|c|c|c|}
\hline & S1 & $\mathbf{S 2}$ & $\mathbf{S 3}$ & S4 & F - ratio \\
\hline \multicolumn{6}{|c|}{ Physicochemicalparameters - mean (SD) } \\
\hline Fat $[\%]$ & $15.00(0.35) \mathrm{c}$ & $19.82(0.20) \mathrm{ab}$ & $18.61(0.14) \mathrm{b}$ & $20.35(0.70) \mathrm{a}$ & $34.44 * *$ \\
\hline Protein [\%] & $10.10(0.20) \mathrm{a}$ & $9.70(0.25) \mathrm{a}$ & $10.20(0.20) \mathrm{a}$ & $9.90(0.32) \mathrm{a}$ & $0.80^{\mathrm{NS}}$ \\
\hline Moisture [\%] & $47.68(0.21) \mathrm{a}$ & $45.68(0.18) \mathrm{b}$ & $44.48(0.52) \mathrm{bc}$ & $43.59(0.61) \mathrm{c}$ & $17.42 * *$ \\
\hline Brix & $26.25(0.25) \mathrm{a}$ & $23.50(0.90) \mathrm{c}$ & $26.40(0.30) \mathrm{a}$ & $25.00(0.50) \mathrm{b}$ & $31.34 * *$ \\
\hline $\mathbf{a}_{\mathbf{w}}$ & $0.815(0.01) \mathrm{a}$ & $0.814(0.08) \mathrm{a}$ & $0.819(0.05) \mathrm{a}$ & $0.824(0.02) \mathrm{a}$ & $0.03^{\mathrm{NS}}$ \\
\hline $\begin{array}{c}\text { Acidity } \\
{\left[\mathrm{cm}^{3} \mathrm{NaOH} /\right.} \\
100 \mathrm{~g}]\end{array}$ & $0.011(0.001) \mathrm{a}$ & $0.011(0.001) \mathrm{a}$ & $0.012(0.001) \mathrm{a}$ & $0.011(0.001) \mathrm{a}$ & $0.028^{\mathrm{NS}}$ \\
\hline pH & $6.78(0.01) \mathrm{a}$ & $6.72(0.01) \mathrm{b}$ & $6.67(0.01) \mathrm{c}$ & $6.73(0.01) b$ & $27.11 * *$ \\
\hline Porosity [\%] & $15.27(2.56) \mathrm{a}$ & $14.67(1.98) \mathrm{a}$ & $7.04(2.10) \mathrm{a}$ & $12.23(3.30) \mathrm{a}$ & $1.95^{\mathrm{NS}}$ \\
\hline \multicolumn{6}{|c|}{ Colorparameters - mean (SD) } \\
\hline $\mathbf{L}^{*}$ & $92.77(0.58) \mathrm{a}$ & $89.74(0.10) \mathrm{b}$ & $93.64(0.70) \mathrm{a}$ & $86.89(0.10) \mathrm{c}$ & $127.05 * * *$ \\
\hline $\mathbf{a}^{*}$ & $-6.64(0.03) \mathrm{c}$ & $-7.17(0.01) \mathrm{d}$ & $-5.35(0.09) \mathrm{a}$ & $-6.16(0.14) b$ & $239.47 * * *$ \\
\hline $\mathbf{b}^{*}$ & $21.93(0.25) \mathrm{c}$ & $28.71(0.18) \mathrm{b}$ & $21.04(0.29) \mathrm{d}$ & $34.09(0.23) \mathrm{a}$ & $193.76^{* * *}$ \\
\hline $\mathbf{C}$ & $22.92(0.15) \mathrm{c}$ & $29.59(0.20) \mathrm{b}$ & $21.71(0.3) \mathrm{c}$ & $34.65(0.22) \mathrm{a}$ & $121.35 * * *$ \\
\hline $\mathbf{h}^{\circ}$ & $106.848(0.12) \mathrm{a}$ & $104.03(0.19) \mathrm{b}$ & $104.26(0.10) \mathrm{b}$ & $100.25(0.16) \mathrm{c}$ & $112.05 * * *$ \\
\hline YI & $33.78(0.21) \mathrm{c}$ & $45.70(0.09) \mathrm{b}$ & $32.09(0.25) \mathrm{c}$ & $56.06(0.18) \mathrm{a}$ & $125.73 * * *$ \\
\hline
\end{tabular}

Different lowercase letters $(\mathrm{a}-\mathrm{d})$ in a row show significant differences between the groups $(\mathrm{p}<0.05)$.

NS - not significant $(\mathrm{p}>0.05),{ }^{*} \mathrm{p}<0.05, * * \mathrm{p}<0.01,{ }^{* * *} \mathrm{p}<0.001$.

In Figure 3 there is presented the structure of the analyzed foams samples used in confectionery industry. Foams samples were made through the whipping process, which has the role of introducing air bubbles into a network of fat droplets to generate the foam. As we can see the pore size varies widely, vegetable cream-based samples showed larger air bubbles trapped in the structure of foam, with a heterogeneous distribution of air voids. The diameter of the air bubbles ranging between $4.36 \mathrm{~mm}$ (S1) to a few micrometers (S2 and S4). According to Goralchuk, 2019 [26] the bubbles shape differs depending on the continuous phase content, thus low concentration phases generate spherical forms while high concentration phases generate dodecahedric forms [26]. Compared to vegetable cream-based samples, the cream-based samples presented smaller air bubbles trapped in the structure of foam and with a more homogeneous distribution of air voids.

\section{Texture properties measurement}

Texture Profile Analysis (TPA) is a double compression test and it is used more and more often for texture measurements due to the fact that it can quantify a large number of texture parameters in a single analysis [27]. Both primary (hardness $(\mathrm{H})$, adhesiveness (A), viscosity $(\mathrm{V})$, cohesiveness $(\mathrm{Co})$, springiness $(\mathrm{S})$ ) and secondary (gumminess $(\mathrm{G})$, resilience $(\mathrm{R})$, fracturability $(\mathrm{F})$ and chewiness $(\mathrm{Ch})$ ) texture profile analysis (TPA) parameters were determined using a texturometer, the results being presented in Table 2. The TPA profile of design confectionery samples are shown in Figure 4 (S1, S2, S3 and S4), and as we can see the highest mechanical strength is shown by S3 sample (Figure 4) $3.48 \mathrm{~N}$, the other foam samples showing close values ranging between $1.52 \mathrm{~N}$ and $1.76 \mathrm{~N}$. The high hardness value of the sample S3 is due to a low porosity (Figure 3). The level of sample aeration influences the texture parameters, thus obtaining products with a soft or tough texture. Besides the influence on the firmness and other texture parameter, the aeration process changes the product appearance, color properties and mouth-feel; providing a sense of fullness in comparison to the non-aerated food [28]. 


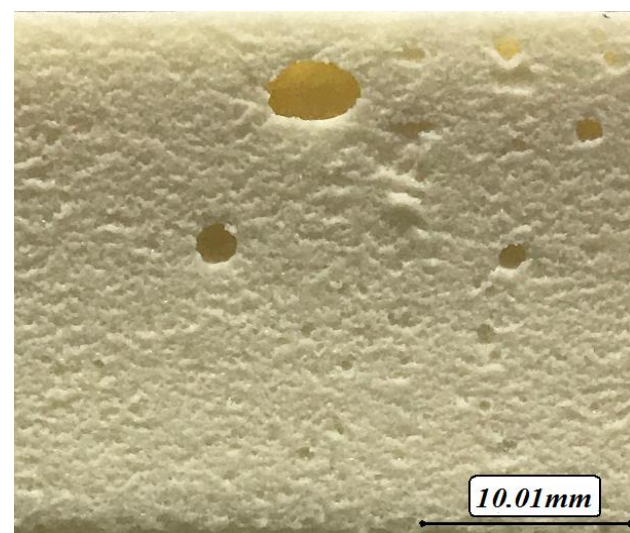

S1

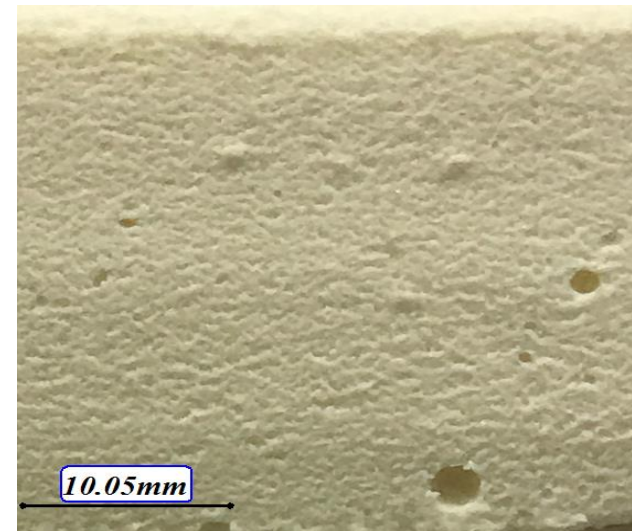

S3

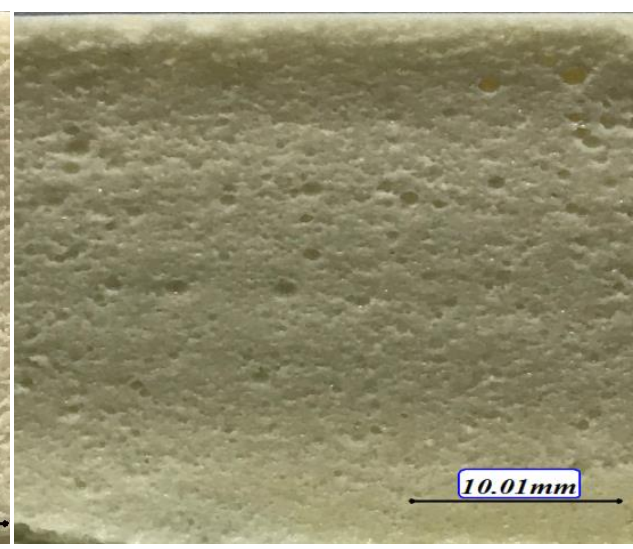

S2

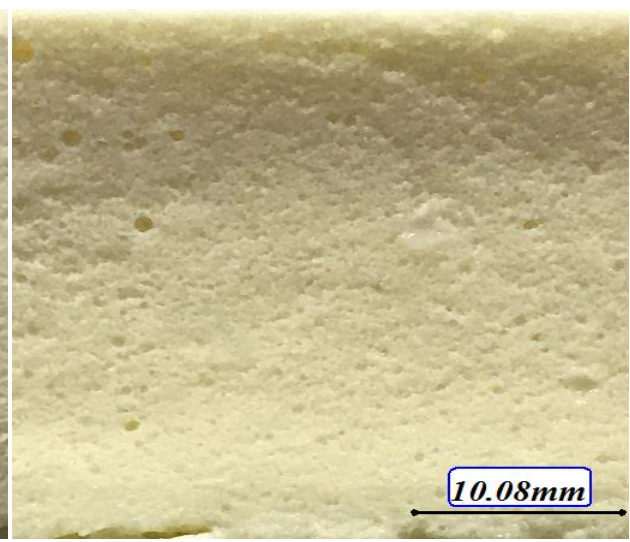

S4

Figure 3. Structure of the analyzed foams used in confectionery

Texture parameters of confectionery foam samples

Table 2

\begin{tabular}{|l|c|c|c|c|}
\hline $\begin{array}{c}\text { Textureparameters - } \\
\text { mean (SD) }\end{array}$ & S1 & S2 & S3 & S4 \\
\hline Hardness [N] & $1.70(0.25)$ & $1.76(0.12)$ & $3.48(0.45)$ & $1.52(0.10)$ \\
\hline Viscosity [N] & $0.40(0.09)$ & $0.38(0.10)$ & $0.64(0.21)$ & $0.26(0.05)$ \\
\hline Fracturability [N] & $0.22(0.05)$ & $0.03(0.03)$ & $0.24(0.01)$ & $0.06(0.01)$ \\
\hline Cohesiveness[\%] & $26.45(0.50)$ & $35.28(0.40)$ & $39.82(0.45)$ & $31.64(0.65)$ \\
\hline Adhesiveness [N·s] & $18.50(0.23)$ & $23.80(0.38)$ & $35.27(0.85)$ & $7.497(0.25)$ \\
\hline Springiness[\%] & $83.89(1.85)$ & $90.53(2.55)$ & $85.73(2.25)$ & $47.25(2.90)$ \\
\hline Gumminess [N] & $0.45(0.10)$ & $0.59(0.11)$ & $1.53(0.10)$ & $0.48(0.10)$ \\
\hline Chewiness [N] & $0.37(0.21)$ & $0.54(0.11)$ & $1.31(0.65)$ & $0.22(0.09)$ \\
\hline Resilience & $1.23(0.50)$ & $1.04(0.45)$ & $0.52(0.35)$ & $0.21(0.10)$ \\
\hline
\end{tabular}




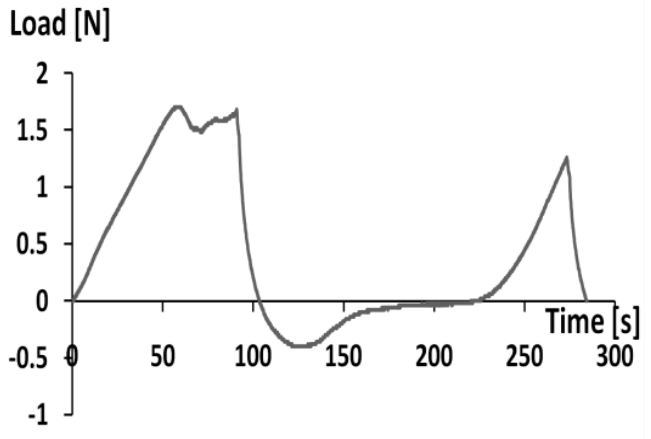

S1

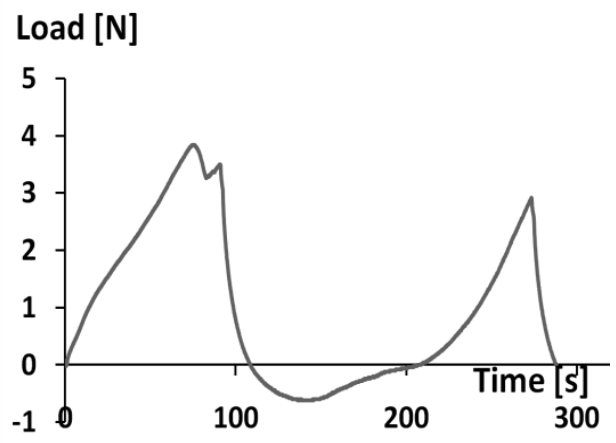

S3
Load [N]

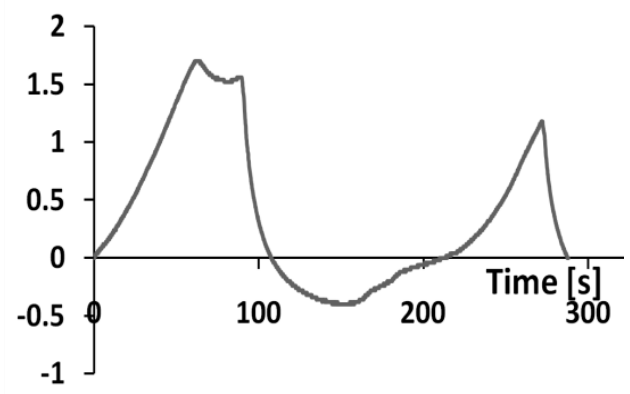

S2

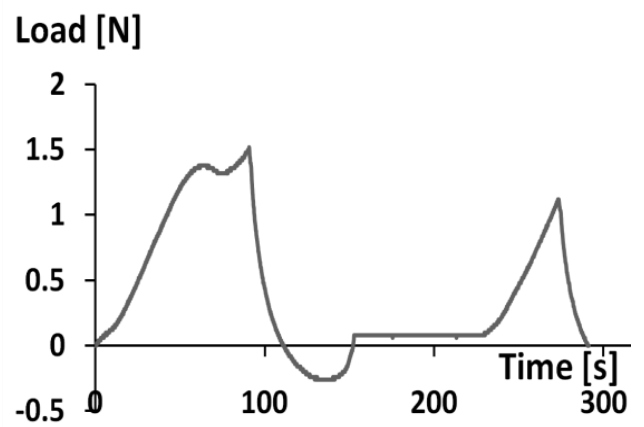

S4

Figure 4. Texture Profile Analysis (TPA) curves of the analyzed foams used in confectionery

Another important aspect is the fact that in case of aerated products the amount of ingested food is reduced, thus decreasing the caloric intake. In some studies, it is shown that [29] food consumption is influenced by both weight and volume of food products. Apart from a high hardness the S3 sample also shows high levels of fracturability $(0.24 \mathrm{~N})$, which implies a more compact and brittle product, also a high viscosity, gumminess, chewiness and cohesiveness. The highest TPA springiness of aerated samples was recorded by S2 (90.53\%) followed by S1 and S3 samples, which had close values; the lowest springiness being recorded by the $\mathrm{S} 4$ sample. The TPA resilience could be defined as how well a sample regains its original position [30]; the analyzed confectionery samples' resilience ranged from 1.23 to 0.21 . 
$\frac{m}{\frac{0}{0}}$

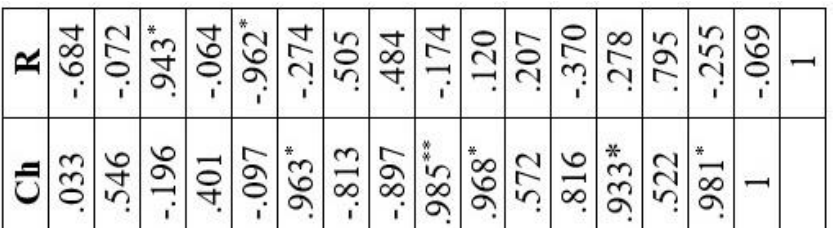

๖

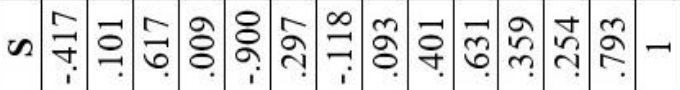

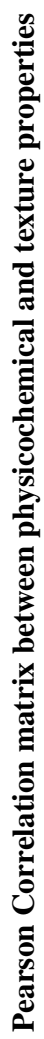

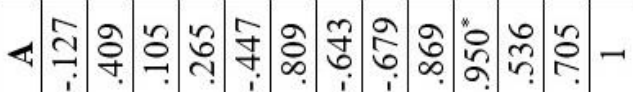

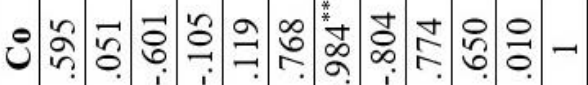

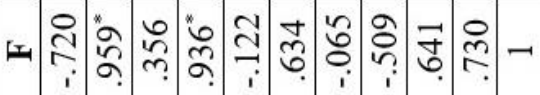

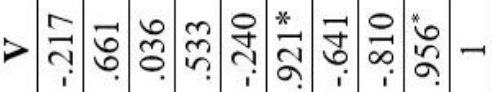

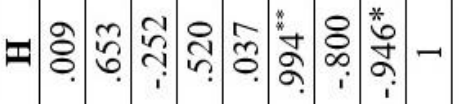

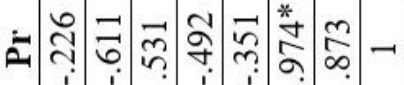

-

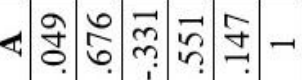

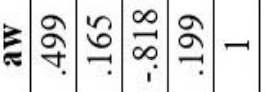

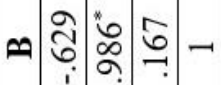

$\sum \begin{array}{lll}0 & 0 \\ \infty & \ddots & \ddots\end{array}-$

- 1 เิ

䨍 -1

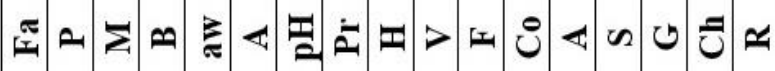

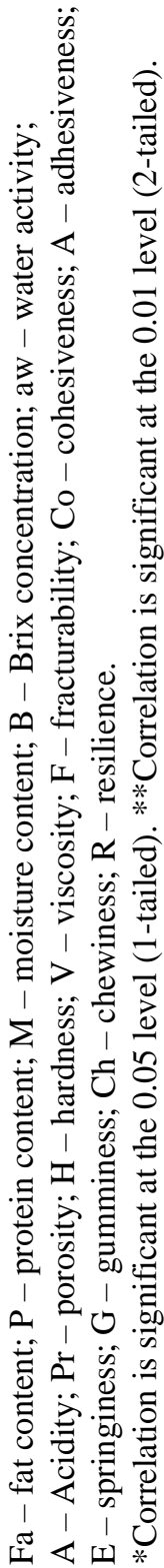




\section{Pearson correlation}

Table 3 presents the Pearson correlation matrix of the physicochemical and texture properties of design confectionery samples. It can be observed that a positive correlation is between the protein content and the concentration of soluble substances $\left(r=0.986^{*}\right)$ and a negative correlation is between sample acidity and the level of aeration (porosity). The TPA texture properties are highly positively correlated among them such as: hardness with viscosity $\left(\mathrm{r}=0.956^{*}\right)$, gumminess with hardness $\left(\mathrm{r}=0.994^{* *}\right)$ and hardness with chewiness $\left(\mathrm{r}=0.985^{* *}\right)$; another positive correlation is between adhesiveness and chewiness $\left(\mathrm{r}=0.933^{*}\right)$. Regarding the correlation of texture properties and physicochemical parameters of analyzed samples it can be observed that the fracturability is positively influenced by the protein content $\left(r=0.959^{*}\right)$ and the concentration of soluble substances $\left(r=0.936^{*}\right)$. The moisture content and water activity have a significant influence on the foam samples resilience $\left(\mathrm{r}=0.943^{*}\right.$ and $\left.\mathrm{r}=-0.962^{*}\right)$ while a significant negative influence on the foams hardness is given by the sample porosity ( $\mathrm{r}=0.946 *)$. According to Fontana, 2006 [22] food products with a high value of water activity are characterized as having a soggy, juicy, chewy and soft texture. A significant positive correlation was recorded between gumminess and chewiness with total acidity $\left(\mathrm{r}=0.993^{* *}, \mathrm{r}=0.963^{*}\right)$, hardness $\left(\mathrm{r}=0.994^{* *}, \mathrm{r}=0.985^{* *}\right)$, viscosity $\left(\mathrm{r}=0.924^{*}, \mathrm{r}=0.968^{*}\right)$, while the porosity was negatively correlated with this two secondary texture parameters $(\mathrm{G}$ and $\mathrm{Ch})$.

\section{Conclusion}

The origin of the raw materials (cream or vegetable cream) used in the production process had an influence on the physicochemical characteristics and color parameters $\left(\mathrm{L}^{*}\right.$ and $\left.\mathrm{a}^{*}\right)$; onefactor analysis of variance ANOVA highlighted these differences at least at a level of $p<0.05$.

The confectionery samples based on vegetable cream presented a whiter and brighter color, larger air bubbles, with a heterogeneous distribution of air voids, while the cream-based foams were more yellow, with smaller air bubbles and a more homogeneous distribution of air voids.

The aeration process of confectionery samples had a negative influence on both primary (hardness) and secondary texture properties (gumminess), thus the introduction of air bubbles led to a lighter and softer texture and the increased volume of the product provides a sense of fullness. Fixing air into the structure of confectionery products represents an alternative in creating new products with special textures and new appearance, which also have a lower caloric intake.

Acknowledgements. The authors acknowledge to SC. MOPAN S.A. for providing the raw materials and production equipment for the experiments. 


\section{References}

1. Misniakiewicz M., (2018), Consumers' expectations and behavior towards confectionery products. Polish market case study, Central and Eastern Europe in the changing business environment, pp. 222-232.

2. Edwards W.P., (2018), The science of sugar confectionery, Royal Society of Chemistry, pp. 1-166.

3. Narchi I., Vial C., Labbafi M., Djelveh, G. (2011), Comparative study of the design of continuous aeration equipment for the production of food foams, Journal of food engineering, 102(2), pp. 105-114.

4. Stanley D.W., Goff H.D., Smith A.K., (1996), Texture-structure relationships in foamed dairy emulsions, Food Research International, 29, pp. 1-13.

5. Granger C., Barey P., Veschambre P., Cansell M., (2005), Physicochemical behavior of oil-in-water emulsions: influence of milk protein mixtures, glycerol ester mixtures and fat characteristics, Colloids and Surfaces B: Biointerfaces 42, pp. 235-243.

6. Decker N.R., Ziegler G.R. (2002), The structure of aerated confectionery, Manufacturing Confectioner, 82(9), pp. 101-108.

7. Campbell G. (2016), Bubbles in Food 2: Novelty, health and luxury, Elsevier.

8. Decker N.R., Ziegler G.R. (2003), Mechanical properties of aerated confectionery. Journal of texture studies, 34(4), pp. 437-448.

9. Campbell G. M., Mougeot E. (1999), Creation and characterisation of aerated food products, Trends in food science \& technology, 10(9), pp. 283-296.

10. Hartel R.W., Joachim H., Elbe V., Hofberger R. (2018), Confectionery science and technology, Switzerland: Springer.

11. Duquenne B., Vergauwen B., Capdepon C., Boone M. A., De Schryver T., Van Hoorebeke L., De Block J. (2016), Stabilising frozen dairy mousses by low molecular weight gelatin peptides, Food hydrocolloids, 60, pp. 317-323.

12. Nielsen S.S. (Ed.), (2010), Food analysis, Springer, New York, pp. 139-141.

13. SR EN ISO 8968-2:2002, Determination of nitrogen content. Block digestion method.

14. AOAC International (2016), Official methods of analysis, 20th edn, AOAC International, Rockville.

15. Tyl C., Sadler G.D. (2017), pH and Titratable Acidity. In: Nielsen S. (eds), Food Analysis, Food Science Text Series, Springer, Cham, pp. 389-406.

16. Pădureț S., Oroian M., Gutt G., Amariei S. (2017), Evaluation of strawberry texture in close relation with their anisotropy, International Journal of Food Properties, 20(2), pp. 247-259.

17. Jung H., Sato T. (2013), Comparison between the Color Properties of Whiteness Index and Yellowness Index on the CIELAB. Textile Coloration and Finishing, 25(4), pp. 241-246.

18. Rosenthal A.J. (2010), Texture profile analysis-how important are the parameters?, Journal of texture studies, 41(5), pp. 672-684.

19. Burey P., Bhandari B. R., Rutgers R. P. G., Halley P. J., Torley, P. J. (2009), Confectionery gels: A review on formulation, rheological and structural aspects. International Journal of Food Properties, 12(1), pp. 176-210.

20. Chen L., Opara, U. L. (2013), Texture measurement approaches in fresh and processed foods - A review, Food research international, 51(2), pp. 823-835.

21. Ergun R., Lietha R., Hartel R. W. (2010), Moisture and shelf life in sugar confections, Critical reviews in food science and nutrition, 50(2), pp. 162-192. 
22. Fontana A. (2006), Water activity for confectionery quality and shelf-life, Senior Research Scientist, pp. 1-20.

23. Lees R. (2012), Sugar confectionery and chocolate manufacture, Springer Science \& Business Media.

24. Jarrett T. N. (2012), Acids in confections, Manuf. Confectioner, 92, pp. 58-63.

25. Ünal Şengör G. F., Balaban M.O., Topaloğlu B., Ayvaz Z., Ceylan Z., Doğruyol, H. (2018), Color assessment by different techniques of gilthead seabream (Sparus aurata) during cold storage, Food Science and Technology, (AHEAD).

26. Goralchuk A., Grinchenko O., Riabets O., Kotlyar O. (2019), Food dispersion systems process stabilization. A review, Ukrainian food journal, 8(4), pp. 699-732.

27. Bourne M. (2002), Food texture and viscosity: concept and measurement, Elsevier, pp. $1-324$.

28. Arboleya J. C., García-Quiroga M., Lasa D., Oliva O., Luis-Aduriz A. (2014), Effect of highly aerated food on expected satiety, International Journal of Gastronomy and Food Science, 2(1), pp. 14-21.

29. Osterholt K.M., Roe L.S., Rolls B.J (2007), Incorporation of air into a snack food reduces energy intake, Appetite 48(3), pp. 351-358.

30. Gupta R.K., Sharma A., Sharma R. (2007), Instrumental texture profile analysis (TPA) of shelled sunflower seed caramel snack using response surface methodology, Food Science and Technology International, 13(6), pp. 455-460. 